\title{
A Review of Output Hypothesis in College English Teaching and Learning
}

\author{
Zhen-xiao LI' ${ }^{\mathrm{a}}$, Zhi-hong LU ${ }^{\mathrm{b}}$ \\ Foreign Language Department, School of Humanities \\ Beijing University of Posts and Telecommunications \\ Beijing, China \\ abriannalee@163.com
}

\begin{abstract}
In current English language learning environment, most Chinese EFL (English as a foreign language) learner's English speaking ability has far fallen behind their writing ability. Many scholars tried to employ Output Hypothesis in college English language courses to improve the effects on students' language output. The paper reviews the development of Swain's Output Hypothesis since 1985. Varied empirical studies were made to prove or reinforce the effects of Output Hypothesis applied in the second language teaching and learning in college. "Output-driven, input-enabled" hypothesis was proposed for university English teaching and learning closely connected with Chinese learners. Some limitations are concluded in the paper.
\end{abstract}

Keywords-Output Hypothesis; second language acquisition; college English; language teaching

\section{INTRODUCTION}

It has been well known that learning English contains four important skills, listening, speaking, reading and writing which are divided into two groups, listening and reading being the input while speaking and writing being the output. With the demands of our society, English output has been more demanding so that more and more learners desire to become more qualified, especially in the aspect of speaking. In 2007, College English Curriculum Requirements (CECR) by China's Ministry of Education announced that college English teaching should pay much attention to developing students' practical skills, especially listening and speaking skills. The CECR also recommended a student-centered and computer-based multimedia college teaching model.

However, in current English learning environment in China, most Chinese English learners' speaking ability falls behind their writing ability in China. Although integrated English language teaching has been put into practice, writing and speaking are often taught separately in language teaching. In addition, to date, the teaching for EFL (English for foreign language) learners has long been applying the input-output sequence models which were researched by a number of applied linguists. However, researchers found that the effects of such teaching model were not satisfied when EFL learners have learned English for years especially for learners at intermediate or advanced level.

Since 1980s, Stephen Krashen's input hypothesis that was

The paper is sponsored by the Social and Science Fund Project

(2012BS05) supported by Beijing University of Posts and

Telecommunications in China. introduced in China and immediately became the focus of language scholars. Input has long been underlined in language teaching and it is known that input and output are often separated in process of teaching. The accumulation of input is necessary for second language acquisition (SLA), but it is far from satisfaction. Actually, Merrill Swain (2008) argued that, to convert our thinking into speaking is more a process of our thinking with a new form of articulation than a retrieving what we memorize [1]. According to Swain's Comprehensible Output Hypothesis, learners wanted to communicate, during the process of which, they noticed their respective linguistic holes, or language gaps, and then they would autonomously carry out the cognitive reflection on the previous output. The modified output would facilitate learners' subsequent learning. She induced comprehensible output played significant roles in three respects that were noticing/triggering function, hypothesis testing function and metalinguistic reflective function. Pushed output is a necessity for learners if they want to obtain higher level of foreign language acquisition.

In the last 30 years, some studies have been made on how the Output Hypothesis affecting learners' language acquisition. References [2] [5] show further analyses and arguments of Swain's Output Hypothesis from different perspectives (Izumi, 2002; Swain 1995, 2005, 2008; Swain and Lapkin, 2003; etc.). In China, Swain's Output Hypothesis has been introduced in the late of 1990s and became broadly known among scholars. Related researches began to carry out mainly in the $21 \mathrm{st}$ Century. More and more scholars focused on the effects of employing Output Hypothesis into EFL teaching and instruction materials to maximize the integrated English skills where diverse teaching activities were conducted in EFL class. In recent years, scholars developed their studies with the assistance of computer technology in the task-based or contentbased language teaching (TBLT).

According to China National Knowledge Internet (CNKI, similar to Web of Science) in China, an increasing number of scholars focus on the studies of Output Hypothesis in college English teaching and learning in China. 


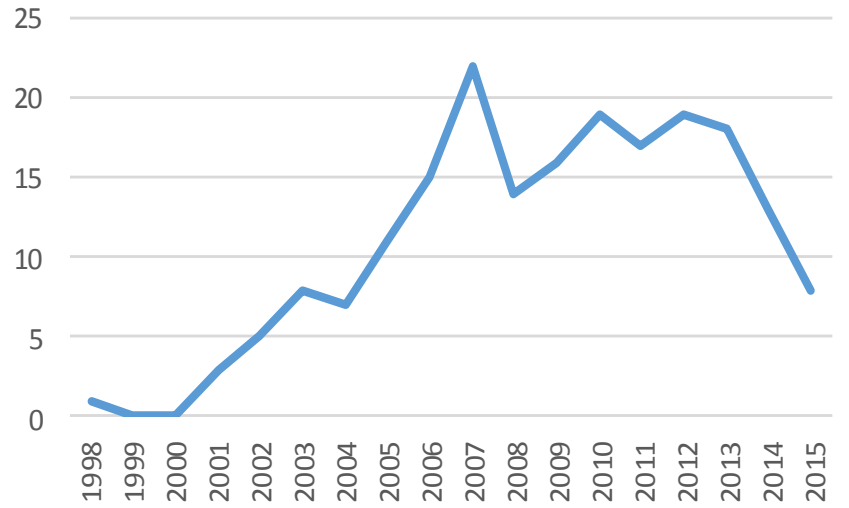

Fig. 1. The amount of journal articles related to Output Hypothesis in college English teaching and learning

\section{THEORETICAL BASIS}

According to Krashen, learners acquired second language by receiving comprehensible input and learners' language acquisition faculty. But Swain were critical to the Input Hypothesis that the interactions and comprehensible input were insufficient for successful SLA. "Conversational exchanges... are not themselves the source of acquisition derived from comprehensible input. Rather they are the source of acquisition derived from comprehensible output: output extends the linguistic repertoire of the learner as he or she attempts to create precisely and appropriately the meaning desired (1985: 252)", Swain stated [6].

Based on her findings in the investigation, she conducted in French immersion contexts in Canada, Swain stated that although immersion students who learned French over a period of eight years, they were not proficient in target language. French proficiency of the immersion students were more advanced than students who took 20, 30 minutes a day for foreign second language (FSL) learning. Later, she (1995) concluded three functions of comprehensible output in SLA, (1) noticing/triggering function; (2) hypothesis testing function; (3) metalinguistic reflective function of output. When learners faced difficulties in communicating, the Output Hypothesis pushed them to monitor and reflect their language holes, thus, the process facilitated students' subsequent learning.

Swain has relabeled "output" as speaking, writing, collaborative dialogue, private speech, verbalizing. "Over the last few decades, there's been a shift in meaning from the 80's to now from output being understood as a noun, a thing, a product to output being understood as a verb, an action, a process", she added in 2008. Swain put forward that "languaging" is the use of language to work through cognitively complex thoughts. It must be meaningful but challenging to study language output because it needs to keep track of information-processing framework of an individual.

\section{RELATED STUDIES ON OUTPUT HYPOTHESIS}

\section{A. Related Studies Abroad}

Swain proposed the famous Output Hypothesis in 1985 based on her investigation of immersion French learning in Canada. Swain and Lapkin (1995) provided data to support that

on occasion L2 (second language) learners became aware of a linguistic problem which pushed learners to modify their output [7]. Pica (1994) elucidated that the importance of modified output to learners' participation in negotiation. When non-native speakers were asked to clarify their output, they would reprocess their output in the direction of well-organized massage comprehensibility [8].

Some scholars also found the effect of modification differed among learners of different genders and different language proficiency. Scholars found that gender differences may also produce different modification, for instance, there were more frequent morphosyntactic modification for males than for females. Learners of different levels have different degrees of modified output [9].

Branden (1997) made an investigation on three groups of 16 child learners of Dutch (NSs and NNSs) who were asked to orally describe pictures to a partner. It showed that language learners who had been pushed in preceding negotiations produced a greater quantity of output, more information and greater range of vocabulary. But there were no significant effects on the syntactic complexity nor the grammatical correctness during the posttest [10].

K.D. Bot (1996) elucidated the psycholinguistic mechanics of Swain's Output Hypothesis relating to Levelt's model of language production and Anderson's learning theory taking the information processing approach as a starting point. Output generated highly specific input that cognitive system needs to build up a coherent set of knowledge and a new declarative knowledge [11].

Comprehensible Output Hypothesis was doubted for lacking of data showing any effect on L2 learning. Shedadeh (2002) explained that the existing researches was mostly descriptive in nature, focusing primarily on occurrence per se rather than acquisition or how output can be a source of competence in the L2 [12].

Hanaoka (2007) conducted a four-stage writing task consisting of output, comparison, and two revisions in Japanese university. In the study, he proved that the output helped EFL learners identify the linguistic features and facilitated subsequent learning of these features. With the focus-on-form writing, learners had a strong motivational advantage in driving forward the subsequent learning process [13].

Uggen (2012) used multiple measures to investigate second language learners' processes in output-input and output sequences with a conceptual replication of Izumi and Bigelow's research [14]. While the test data did not support an effect of output on specific attention to grammar in subsequent text, the qualitative stimulated recall data revealed how output influences learners' subsequent noticing of vocabulary and/or 
awareness of their linguistic limitations concerning grammar structures.

In sum, scholars made diverse empirical studies to prove the effects on Output Hypothesis applied in language teaching, especially the EFL teaching. When learners were faced with difficulties in communication, they would notice their language gap and reflect on their original output, then they reprocessed their output, the process of which would be facilitative to their subsequent learning in those features. Studies also demonstrated that advanced students who were able to shorten the duration of internalizing of language knowledge, were more beneficial from the modified output.

\section{B. Related Studies in China}

In China, scholars began to pay attention to Swain's Output Hypothesis at the turn of the 21 st Century. There were mainly two kinds of researches. One was to introduce and discuss Swain's Output Hypothesis; the other was empirical studies of practical teaching.

Task-based Language Teaching is an effective teaching method to develop students' communicative ability in the target language. Students were delivered to different kinds of tasks including culture, personal favorite and what happened in their daily lives. Most researchers, therefore, applied the Output Hypothesis with connection of tasked-based or contentbased teaching in the learner-centered education environments.

$\mathrm{Xu}$ (2002) stated a reform on the audio-visual and speaking course offered to the third year English majors based on input and output theories. The quality of oral output was restricted in teaching method, instructors and learners' participation in class Thus to enrich the teaching materials and methods led students to internalize knowledge to improve the oral quality, for instance, generalizing, sorting, listing and comparing [15].

Zhu (2007) made a teaching design in the language philosophy, where some activities in a theme-based unit provide a succession of intrinsically-linked interior and exterior contexts for the whole learning process by integrating all skill exercises [16]. The action research suggested that it was necessary to pay more attention to interactive activities and design effective thematic listening and phonic exercises in this output-oriented model.

Similarly, an empirical study (Guo and Qi, 2009) was carried out aiming at increasing the learners speaking ability through strengthening students' listening. The results of the study show that speaking ability of the experimental class has obvious increasing than the control class [17].

It is known that one aspect of the important oral proficiency is discourse proficiency. According to Li's (2011) investigation, positive vocabularies and prefabricated language chunks rank first influencing discourse proficiency. Then writing and applied grammatical knowledge and self-mending ability ranks second [18].

Output-driven hypothesis was proposed by Wen in 2007 that emphasized the practical application in college English. References [19] and [20] exemplify scholars (Fang and Xia, 2010; Zhao 2012; etc.) conducting empirical studies on the possibilities of output-driven hypothesis in speaking, writing and interpreting courses. Later, it was improved to "outputdriven, input-enabled" theory which emphasized the importance of input as well as output in university English [21] She with her team conducted the initial attempt to develop the new theory of foreign language instruction in mainland China.

Scholars have made some practical applications of Output Hypothesis in EFL teaching, so as to improve learners' English output proficiency, fully responsive to CECR. Studies showed that output played a useful role in both helping learners identify their linguistic features and push them to modify their output. Related output-oriented teaching approaches drove learners to try to be accurate and well-organized in expressing their ideas, which was sure to have a positive domino effect on EFL learning. Learners' characteristics were also taken into consideration, such as learner autonomy, confidence and anxiety.

\section{CONCLUSION}

The necessity of comprehensible input has long been admitted in second language learning. Particularly, in the monolingual environment in China, a large amount of comprehensible input is greatly significant. According to Swain, output is insufficient, then she proposed Output Hypothesis. She emphasized that when learners faced difficulties in communicating, the Output Hypothesis pushed them to monitor and reflected their language holes, and the modified output could enhance their cognitive knowledge of language and facilitated their subsequent second language learning. Some empirical studies were conducted to prove or reinforce the possibility of Output Hypothesis in promoting EFL learners' output proficiency in second language teaching.

However, there exist some limitations. Many of these empirical studies were not conducted continuously, otherwise, more sound and effective arguments and findings can be provided and put into practice extensively. In addition, from the microscopic view empirical studies lack of the information process with the modern technology applied in language teaching. It would be more convincing and desired to keep track of what goes on between learners' original output and the reprocessed form, which is conducive to both teaching and learning.

It is hoped that the review shed some light on the effective application of Out-put Hypothesis in college English learning and teaching in mainland China.

\section{REFERENCES}

[1] M. Swain, and L. Yang (Interviewer), "Output Hypothesis: Its history and its future," Foreign Language Teaching and Research, vol. 40, pp. 45-49, 2008.

[2] S. Izumi, "Output input enhancement, and the noticing hypothesis: an experimental study on ESL relativization," Studies in Second Language Acquisition, vol. 36, pp. 541-77, 2002.

[3] M. Swain, "Three functions of output in second language learning," in G. Cook and B. Deidlhofer, Eds. Principle and Practice in Applied Linguitics. Oxford: Oxford University Press, 1995.

[4] M. Swain, "The output hypothesis: Theory and research," in C. Doughty and J. Williams, Eds. Handbook on Research in Second Language 
Learning and Teaching. Mahwah, NJ: Lawrence Erlbaum Associates, 2005.

[5] M. Swain, and S. Lapkin, "Talking it through: Two French immersion learner's response to reformulation," International Journal of Educational Research, vol. 37, pp. 285-304, 2003.

[6] M. Swain, "Communicative competence: some role of comprehensible input and comprehensible output in its development," in S. Gass and C. Maddern, Eds. Input in Second Language Acquisition. Rowley, MA: Newbury House, 1985.

[7] M. Swain, and S. Lapkin, "Problems in output and the cognitive process they generate: a step towards second language learning," Applied Linguistics, vol. 16, pp. 371-391, 1995.

[8] T. Pica, "Research on negotiation: what does it reveal about second language learning conditions, processes and outcomes?" Language Learning, vol. 44, pp. 493-527, 1994.

[9] T. Pica, L. Holliday, N. Lewis and L. Morgenthaler, "Comprehensible output as an outcome of linguistic demands on the learner," Studies in Second Language Acquistion, vol. 11, pp. 63-90, 1989.

[10] K.V. den Branden, "Effects of negotiation on language learners' output," Language Learning, vol. 47, pp. 589-636, 1997.

[11] K.D. Bot, "Review article: The psycholinguistics of the output hypothesis," Language learning, vol. 46, pp. 529-555, 2006.

[12] A. Shehadeh, "Comprehensible output, from occurrence to acquisition: An agenda for acquisitional research," Language Learning, vol. 52, pp. 597-647, 2002.
[13] O. Hanaoka, "Output, noticing, and learning: An investigation into the role of spontaneous attention to form in a four-stage writing task," Language Teaching Reseaching, vol. 11, pp. 459-479, 2007.

[14] M.S. Uggen, "Reinvestigating the noticing function of output," Language Learning, vol. 62, pp 506-540, 2012.

[15] M. Xu, "Optimizing input as to activate output $-\mathrm{a}$ reform on the audio-visual and speaking course," Computer-assisted Foreign Language Education, pp. 34-37, 2002.

[16] F. Zhu, "The practice of writing to speaking in the whole language philosophy based on action research," Foreign Lanugage World, pp. 17 27, 2007.

[17] H. Guo and D. Qi, "An empirical study on input and output hypothesis," Foreign Language Research, pp.132-135, 2009.

[18] S. Li, "Influences of linguistic variables on EFL learners' discourse proficiency: an experimental study on oral English teaching," Journal of Zhejiang International Studies University, pp.12-14, 2011.

[19] F. Fang and B. Xia, "Construction of competence-based, output-driven English course group," Shangdong Foreign Language Teaching tool, pp. 3-8, 2010.

[20] J. Zhao, "A new teaching model of oral English based on the 'outputdriven hypothesis'," Foreign Langauge Research, pp. 331-334, 2012.

[21] Q. Wen, “'Output-driven, input-enabled': a tentative theory of foreign language classroom instruction for universtiy students," Foreign Language Education in China (Quarterly), vol. 7, pp. 3-12, May, 2014. 